\title{
Materials research advocacy affects the US federal budget
}

www.mrs.org/advocacy

\section{By Kevin Whittlesey}

This article is the first in a series from the Government Affairs Committee's Advocacy Education and Outreach Subcommittee intended to inform the MRS community about important aspects of science advocacy.

A dvocating for strong budgets for federal agencies that fund materials research is central to the advocacy agenda of the Materials Research Society (MRS). But how does the process of determining the budget for particular federal agencies work, and how can we, the materials community, influence it?

An important place to start is to understand what the total federal budget looks like. In FY 2016, the US federal budget was around $\$ 3.5$ trillion. About two-thirds of that amount is socalled mandatory spending. Mandatory spending goes to programs such as Social Security, Medicare, and Medicaid. Those programs are written into law in such a way that they continue to be funded each year without any further action required by Congress. An additional $6 \%$ of the federal budget goes to pay interest on the national debt. That leaves about one-third of the budget as so-called discretionary spending. Congress has only that small piece of the budget to fund all other federal agencies and programs, including materials research programs that are of interest to MRS members.

An important distinction to understand regarding the federal budget process is the difference between authorization and appropriation. An authorization is a law passed by Congress providing the federal government with the legal authority to fund a particular agency or program. An

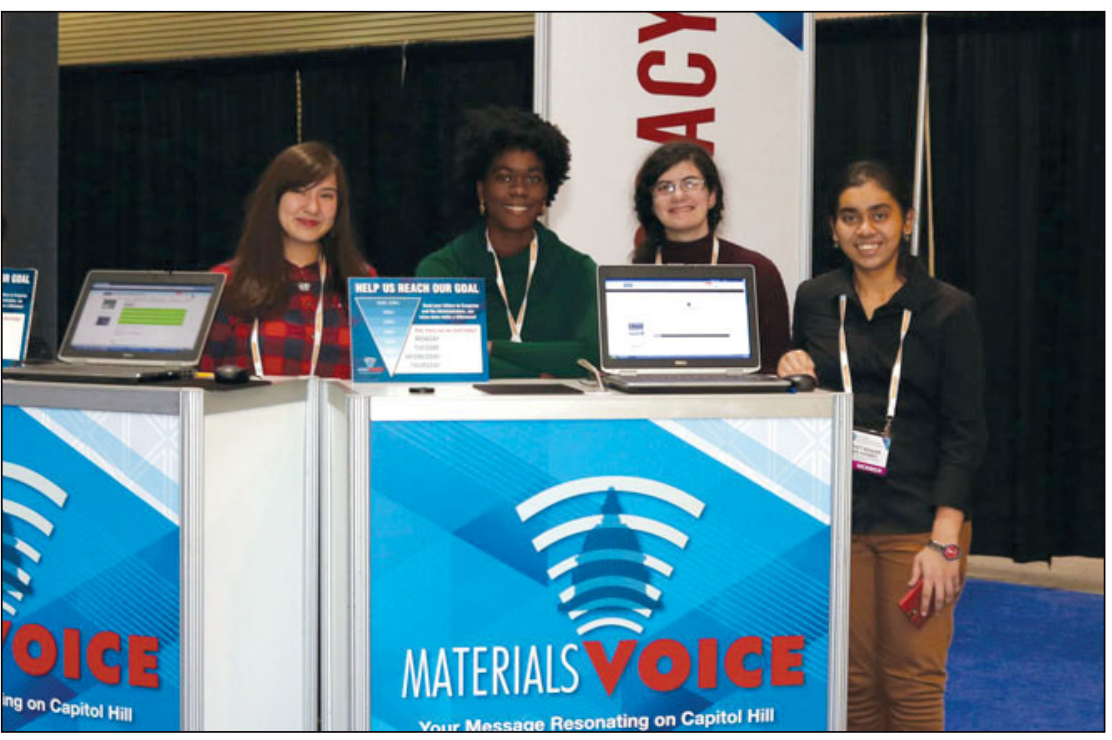

Volunteers at the Materials Voice Booth at a MRS Meeting. appropriation bill, by contrast, specifies the funds that will be given to and spent by a particular agency. For example, many MRS members are familiar with the Advanced Research Projects Agency-Energy (ARPA-E). Congress created, or authorized, ARPA-E in 2007 in the America COMPETES Act. That law stated that funds could be directed to ARPA-E, but the law was not able to provide funds. In 2009, ARPA-E received its first appropriation of $\$ 400$ million. It is a two-step process, and advocacy groups, including MRS, often seek to influence aspects of authorization as well as appropriation bills.

What are the steps involved with developing and passing the federal budget? The budget process begins with the president sending a budget request to Congress, usually in February, for the subsequent fiscal year, which begins October 1. Next, the House of Representatives and the Senate each draft and pass a budget resolution and reconcile the differences between the two, arriving at what is called a concurrent resolution. The budget resolution may or may not be aligned with the president's wishes, as articulated in the budget request. The congressional budget resolution sets a roadmap for what Congress will spend across 20 broad categories, known as budget functions. These budget functions are sometimes referred to as "302(a) allocations," named for the article of the Congressional Budget Act defining this process. Note, however, that passing a budget resolution is not a required 
step. If there is not a new budget resolution, the previous year's resolution is maintained.

Within the 302(a) allocations, the budget resolution directs the roughly one-third of the budget representing the discretionary spending to the Appropriations Committees for the House of Representatives and the Senate. The Appropriations Committees, in turn, are each divided into 12 subcommittees, each with its own jurisdiction. The funding levels for the Appropriations subcommittees are specified, which are sometimes referred to as 302(b) allocations. The 302(b) allocations are very important numbers for advocacy groups. Each 302(b) allocation is the total amount available to each Appropriations subcommittee to divide among all of the federal agencies and programs within its respective jurisdiction. To accomplish this, each subcommittee develops an Appropriations bill to detail how its money will be allocated. As you might imagine, within each of those bills, there are an enormous number of competing interests all vying for the same limited resource pool. Attempting to influence how much money each Appropriations subcommittee assigns to particular programs is a particularly active target for MRS and other advocacy groups. As one gets farther along in the process, it becomes more difficult to change the appropriations levels, requiring amendments to existing language, thus convincing members of Congress of the importance of particular programs while they are in the process of drafting the bill to set programmatic funding levels is an important target for advocacy groups.

The federal appropriations legislation must be passed by Congress and signed into law each year by October 1 , when the new federal fiscal year starts. In theory, the House and Senate must pass each of the 12 appropriations bills, negotiate and resolve differences between the bills, and then each chamber of Congress must pass identical versions of the bills. In this highly partisan environment, that is a challenging process. If that does not happen, Congress has to pass a continuing resolution, sometimes referred to as a CR, which is, in essence, an extension of the previous fiscal year's budget. Continuing resolutions have become increasingly common. A continuing resolution has significant impact on the scientific research community since there is typically no opportunity to adjust the funding levels, either to develop new programs or to adjust the budget for the cost of inflation. We are currently operating under a continuing resolution. It should be noted, however, that in some circumstances, a continuing resolution could be viewed positively in the event that Congress and/or the administration were proposing to cut science agency budgets, as is the case this year.

As already described, there are many places throughout this process at which groups attempt to influence the decisionmaking process. This can apply to not only high-level total budgets for entire agencies, but some groups may only care about one specific program within one particular agency. The level of granularity to which advocacy groups go within the federal budget varies widely.

As a general rule, MRS advocates for increases in the budgets of federal agencies critical to materials research, such as the Department of Energy (DOE), the National Science Foundation, and the Department of Defense (DoD). We sometimes advocate for specific programs, such as the basic and applied research programs within the DoD or the ARPA-E program within the DOE. But, in general, since materials funding is decentralized across multiple programs, we tend to advocate for increased research funding to agencies that are important to physical sciences research. This broad approach has both positive and negative impacts on our advocacy efforts. It is helpful that we seek to increase the general top-level funds to particular agencies, but it also means that we do not have a single line item in the budget that we can point to as critical for our field. And just because the budget for a particular agency is increased does not necessarily mean that those additional funds will go to materials science, much less directly to the MRS community.

Despite these challenges, MRS continues to advocate for federal programs that will help elevate physical sciences research in the United States, with a particular interest in materials research programs. Participation by MRS members is an important part of our advocacy efforts. The MRS Government Affairs Committee (GAC) is the voice of MRS members on policy and advocacy efforts and sponsors a number of advocacy activities. Among those, MRS takes a delegation of members to Washington, DC, each year to meet with congressional representatives and directly communicate the importance of materials research and other issues of importance and the federal funding levels that we'd like to see realized. Furthermore, we empower MRS members to convey similar advocacy messages by way of the Materials Voice kiosk at MRS Spring and Fall Meetings. Materials Voice provides a platform from which Meeting attendees can easily send letters to their congressional representatives and the White House about topics important to materials research. Congress treats these letters from constituents very seriously, and they are an important advocacy tool. GAC is working to continue to expand our advocacy efforts and empower MRS members to be effective advocates for materials research and for science more broadly. In an uncertain climate for federal funding, the engagement of more volunteers as advocates for science is required.

Note: MRS advocacy is focused on funding for materials research in the United States. This also affects materi als research worldwide through funded international collaborations. MRS is beginning to explore advocacy efforts in other countries and continents.

If you have any comments or feedback on this article or to get involved, please email publicaffairs@mrs.org. To receive periodic updates on other policy-related matters, please go to www.mrs.org/my-mrs and subscribe to "INTERSECTIONS" and "Advocacy and Policy News." Find GAC on Facebook at Materials Science Policy, on Twitter at @MaterialsSciPol, or our podcast "Materials Minute" in iTunes. 